\title{
Utilization of Potato Haulms: An Alternate Feed Resource for Livestock
}

\author{
Pushpendra Koli*, Asim Kumar Misra and Krishna Kunwar Singh \\ Indian Grassland and Fodder Research Institute, Jhansi, India \\ *Corresponding Author: Pushpendra Koli, Indian Grassland and Fodder Research Institute, Jhansi, India.
}

Received: May 22, 2019; Published: July 11, 2019

DOI: $10.31080 /$ ASAG.2019.03.0568

\begin{abstract}
In this study, an attempt has been made to explore potato haulms (PH) based silage as an alternate feed resource for livestock. Potato haulms were ensiled along with green chopped oat in different ratios (T1: PH alone, T2: 80:20, T3: 60:40, T4: 50:50) or with molasses (T5: PH with 2\% molasses, T6: PH with 4\% molasses) or with wheat straw (T7: PH with 15\% wheat straw) on fresh basis for a period of 45 days at room temperature in plastic silo. The CP content of potato haulms was $18.45 \%$ at $16.81 \%$ DM. Other parameters including NDF, ADF, EE and ash were 28.45\%, 19.4\%, 6.27\% and 10.23\%, respectively. After 45 days of ensiling, experimental silos were opened and samples were evaluated for further silage quality. The $\mathrm{pH}$ values were higher (4.55 to 6.42) than the normal range (3.8-4.2) suggested for good quality silage. DM was ranged from $18.22 \%$ to $39.26 \%$. The lactic acid content and ammonia-N\% was ranged between 0.02 to $3.88 \%$ and 10.33 to $35.40 \%$ respectively. The results indicated that potato vines/ haulms are high in protein content (>18\%) and it can be ensiled along with oat in the ratio of 50:50 for livestock feeding as an alternate feed resource in the form of silage.
\end{abstract}

Keywords: Potato Haulms; Silage; Hay; Livestock Feed; Molasses

\section{Abbreviations}

PH: Potato Haulms; DM: Dry Matter; NDF: Neutral Detergent Fiber; ADF: Acid Detergent Fiber; EE: Ether Extract; CP: Crude Protein; OM: Organic Matter; CHO: Carbohydrates; ME: Metabolizable Energy; N: Nitrogen; P: Phosphorous; K: Potassium; Na: Sodium; Ca: Calcium; K: Potassium; Mg: Magnesium; Mn: Manganese.

\section{Introduction}

India has one of the largest livestock populations in the world, and one of its notable characteristics is that that almost its entire feed requirement is met from crop residues and byproducts [1]. At present, the country is facing a net deficit of $35.6 \%$ green fodder, $10.95 \%$ dry fodder and $44 \%$ concentrate feed ingredients. Therefore, India is struggling to cater livestock feed and fodder deficiency. To mitigate such a wide gap either fodder production should have to increase or we have to use the non conventional feed resources. In this context, a relatively abundant potential source of animal feed is vegetable and fruit byproducts. Among these potatoes contribute significantly in Indo-Gangetic plains during winter season. It is a highly valued vegetable crop plant. Hence, these a huge amount of potato haulms can be a supplement in terms of green fodder. Potato crop became a cash crop due to which its popularity in farmer is increasing. Whereas farmers are not giving efficient land for fodder production which leads to scarcity of fodder in terms of green and dry to the available livestock. In India about 48 million tonnes of potato is produced annually which produces around 3 million tonnes of potato haulms and these haulms usually thrown in the field without much reuse except house hold burning etc. The leaves and stems collectively called the haulm. It has been reported that ensiled potato haulms are equivalent to corn silage in their feeding values [2]. The composition and nutritive value of protein concentrates from potato haulms of different varieties were also evaluated by Hanczakowsk., et al. [3]. The nutritional value of pressed potato vine silage was evaluated through livestock feeding trial [4]. Green potato haulms were also tried for silage as alone and with combination of other straw material and hay at different wilting period, among those silage from wilted vines and contains hay were found suitable [5]. By keeping all these points in mind there is one possible use for these potato haulms for livestock feeding as an alternate feed resource in the form of silage. 


\section{Materials and Methods}

Collection of potato haulms, oat and wheat straw

Potato haulms were collected during potato tuber harvesting stage for two times during month of November and February from the Central Potato Research Institute, Gwalior, (Madhya Pradesh). The potato haulms were cut at 5-10 $\mathrm{cm}$ above ground level. Oat and wheat straw were collected from Experimental Farm of Indian Grassland and Fodder Research Institute, Jhansi. The experiment was repeated two times comprising eight treatments with three replications. All herbage was weighed prior to ensiling.

\section{Designing of experiments}

Laboratory silos constructed dimension of $14.15 \mathrm{~cm} \mathrm{X} 11.40 \mathrm{~cm}$ plastic boxes that were fitted with end-cap was utilized for the trials. The top end of silos was wrapped with packing tape to prevent seepage of liquids and to make an air tight seal for proper fermentation. During ensiling the potato haulms (around 17\% DM) and oats (around 29\% DM) were then chaffed and mixed in the different ratios $\left(\mathrm{T}_{1}-\mathrm{PH}\right.$ alone, $\mathrm{T}_{2}-80: 20, \mathrm{~T}_{3}-60: 40, \mathrm{~T}_{4}-50: 50, \mathrm{~T}_{5}-0$ at alone, $\mathrm{T}_{6}$-PH with $2 \%$ molasses, $\mathrm{T}_{7}$ - $\mathrm{PH}$ with $4 \%$ molasses and $\mathrm{T}_{8}-\mathrm{PH}$ with $15 \%$ wheat straw) on fresh basis. All silos were stored in a similar environment at room temperature for a period of 45 days.

\section{Determination of proximate constituents}

Chemical analysis for proximate constituents and fiber fractions of green potato haulms were done following methods of AOAC [6] and Van Soest., et al. [7], respectively. After completion of ensiling period the silos were opened and silage quality was evaluated using analytical techniques [8,9]. Dry matter (DM), crude protein (CP), ether extracts (EE), NDF, ADF and ash of ensiled samples were determined.

\section{Mineral profiling}

For important minerals mineral estimation dried and sieved potato haulms were digested with tri-acid mixture in a hot plate at a high temp. $\left(120-270^{\circ} \mathrm{C}\right)$. The extractable aliquot was subjected to estimation of calcium (Ca), magnesium (Mg), manganese (Mn) in a Flame Atomic Absorption Spectrophotometer (Make-Varian, Model $240 \mathrm{FS}$ ). Sodium ( $\mathrm{Na}$ ), and potassium (K) were measured in a flame photometer while phosphorus (P) was determined spectrophotometrically. SAS (Version 9.3; 2012) was used for statistical analysis.

\section{Results and Discussion}

Potato haulms chemical composition

The chemical compositions of potato haulms and hay are presented in Table 1. As it shown potato hay is a good source of energy with $8.74 \mathrm{MJ} / \mathrm{kg}$ DM of metabolisable energy and dietary fiber with very good dry matter digestibility about $72.3 \%$ and $53.69 \%$ in po- tato hay and haulms respectively. Crude protein is slightly more in case of potato haulms compare to hay. Very good amount of protein content about $200 \mathrm{~g} / \mathrm{kg}$ and high dietary fiber of about $323.2 \mathrm{~g} / \mathrm{kg}$ NDF found in potato haulms.

\begin{tabular}{|l|c|c|}
\hline \multicolumn{1}{|c|}{ Parameters } & PH & Hay \\
\hline Dry matter & 18.40 & 88.50 \\
\hline OM & 94.09 & 89.45 \\
\hline Crude Protein & 20.00 & 14.7 \\
\hline NDF & 32.32 & 50.44 \\
\hline ADF & 21.55 & 40.15 \\
\hline EE & 4.40 & 3.50 \\
\hline Crude Fiber & 22.35 & 30.22 \\
\hline Ash & 5.97 & 10.55 \\
\hline Dry matter digestibility & 53.69 & 72.30 \\
\hline ME (MJ/kg) & 7.74 & 8.74 \\
\hline Soluble CHO & 3.8 & - \\
\hline
\end{tabular}

Table 1: Proximal chemical composition (\% of Dry Matter) of potato haulms and hay.

Chemical composition analysis revealed that potato haulms had comparable $\mathrm{CP}$, but higher ash content when compared with alfalfa hay $(20.8 \%$ vs. $9.6 \%$ in alfalfa), these results are consistent with those reported by Salehi et al. (2014).Chemical composition analysis revealed that potato haulms and hay both have a significant amount of protein and energy on this basis potato haulms can be a good supplement of livestock feed.

\section{Mineral profiling}

For mineral profiling, some of the important minerals had been analyzed in potato haulms with help of AAS. From the table 2 results were observed that observed $\mathrm{K}(0.825 \mathrm{~g} / \mathrm{kg})$, Ca $(2.12 \mathrm{~g} / \mathrm{kg})$, $\mathrm{Na}(155 \mathrm{mg} / \mathrm{kg})$, Nitrate N (31.5 mg/kg), Mg (515.5 mg/kg), P (176.5) and $\mathrm{Mn}(\mathrm{mg} / \mathrm{kg})$. Among analyzed mineral compositions $\mathrm{Ca}, \mathrm{K}$ and $\mathrm{Mg}$ are in good quantity compare to other minerals.

\begin{tabular}{|l|c|}
\hline Minerals & Concentration (mg/kg) \\
\hline $\mathrm{NO}_{3}-\mathrm{N}$ & 31.5 \\
\hline $\mathrm{P}$ & 176.5 \\
\hline $\mathrm{K}$ & 825 \\
\hline $\mathrm{Na}$ & 155 \\
\hline $\mathrm{Ca}$ & 2120 \\
\hline $\mathrm{Mg}$ & 515.5 \\
\hline $\mathrm{Mn}$ & 11.8 \\
\hline
\end{tabular}

Table 2. Mineral contents in Potato haulms (leaves + stems). 
This shows potato haulms is having very good source of calcium and magnesium which play may important role in growth and development of animal body. And role of calcium is so important in lactating animals too.

Ensiling characteristics of potato haulm in different combinations

The chemical composition of ensiled potato haulms as alone and in combination with oat and wheat straw at different proportion are presented in Table 3. Four parameters namely pH, DM, Lactic acid and ammonia- $\mathrm{N}$ are the basic silage characteristics. DM was ranged from $18.22 \%$ to $34.60 \%$ with highest in case of T4. $\mathrm{pH}$ value was observed in all combinations between 4.55 to 6.42 with lowest in T4- PH+ Oat (50:50). The lactic acid content was found low in T1-PH (0.02\%) while maximum about more than 1 per cent in treatment 3 and 4 with $\mathrm{PH}+$ Oat (50:50) and $\mathrm{PH}+$ Oat (60:40) respectively. Ammonia-N\% was recorded lowest is 18.88 and highest is 35.40 in $\mathrm{T} 4-\mathrm{PH}+$ Oat (50:50) and $\mathrm{T} 8-\mathrm{PH}+15 \%$ WS respectively. Good silage should have less amount of ammonia-N.

In utilization of preserved livestock feed maize silage is well known and it had been explored extensively throughout the world. By adopting this ideal silage is having characteristics $\mathrm{pH}$ range (3.8 - 4.2) and DM per cent varies (30-35) with good aroma. Here, among all the treatments the basic ensiled characteristics of treatment $4 \mathrm{PH}+$ Oat (50:50) had sown almost similar trend on that basis this combination can be utilized as non-conventional feed in form of silage.

\begin{tabular}{|l|c|c|c|c|c|}
\hline S.N. & Treatments & DM\% & pH & LA\% & $\mathbf{N H}_{3}-\mathbf{N} \%$ \\
\hline 1 & $\mathrm{~T}_{1}$-Potato Haulm (PH) & 18.22 & 5.98 & 0.02 & 30.45 \\
\hline 2 & $\mathrm{~T}_{2}-\mathrm{PH}+$ Oat (80:20) & 29.90 & 4.98 & 1.00 & 24.50 \\
\hline 3 & $\mathrm{~T}_{3}-\mathrm{PH}+$ Oat (60:40) & 30.21 & 4.68 & 1.01 & 24.30 \\
\hline 4 & $\mathrm{~T}_{4}-\mathrm{PH}+$ Oat (50:50) & 34.60 & 4.56 & 1.01 & 22.05 \\
\hline 5 & $\mathrm{~T}_{5}-\mathrm{PH}+2 \%$ molasses & 24.55 & 5.55 & 0.42 & 20.45 \\
\hline 6 & $\mathrm{~T}_{6}-\mathrm{PH}+4 \%$ molasses & 25.62 & 5.21 & 0.96 & 18.88 \\
\hline 7 & $\mathrm{~T}_{7}-\mathrm{PH}+15 \% \mathrm{WS}$ & 25.67 & 6.42 & 0.18 & 35.40 \\
\hline
\end{tabular}

Table 3. Ensiling characteristics of different combination of potato haulm

\section{Conclusion}

From the experiment it was concluded that potato haulms which is about 4-6 percent of whole plants can contribute to about 2.95 million tons of green forage, either in the form of hay or silage. Potato haulms can be ensiled along with oat in the ratio of 50:50 for livestock feeding as an alternate feed resource in the form of silage.
Thus green fodder deficit could reduce to the tune of $5 \%$ during lean period, if preserved safely.

\section{Acknowledgments}

Authors wishes to thank Central Potato Research Station, Gwalior for providing the potato haulms and Director IGFRI, Jhansi for helping set up the silage experiment.

\section{Bibliography}

1. Dikshit AK and Birthal PS. "India's livestock feed demand: Estimates and projections". Agricultural Economics Research Review 23.1 (2010): 15-28.

2. Watson SJ and Nash MJ. The conservation of grass and forage crops oliver and boyd, Edinburgh (1960): 546.

3. Hanczakowski P and Makuch M. "The composition and nutritive value of protein concentrates from potato haulms". Potato Research 23.1 (1980): 1-8.

4. Parfitt DE., et al. "The nutritional value of pressed potato vine silage”. American Potato Journal 59.9 (1982): 415-423.

5. Nicholson JWG., et al. "The feeding value potential of potato vines". Canadian Journal of Animal Science 58.4 (1978): 559569.

6. AOAC. Official Methods of Analysis 17th Edition. Association of Official Analytical Chemists, Washington DC, USA (2000).

7. Van Soest PJ., et al. "Methods of dietary fiber, neutral detergent fiber and non-starch polysaccharides in relation to animal nutrition". Journal of Dairy Science 74 (1991): 3583-3597.

8. Singh AP and Pandit NN. "Studies on fermentation of sorghum silage during storage: effect of urea and molasses". Animal Feed Science and Technology 3 (1978): 299-307.

9. Nag SK., et al. "Nutritional value of top feeds from Dharwad region of Karnataka with special reference to mineral contents". Range Management and Agroforestry 38.1 (2017): 108-114.

Volume 3 Issue 8 August 2019 (C) All rights are reserved by Pushpendra Koli., et al. 